\title{
A study of the effects of frozen storage on certain functional properties of meat and fish protein
}

\author{
F. JIMÉNEZ COLMENERO and A. J. BORDERIAS
}

\section{Summary}

This paper presents a study of the effects of frozen storage on certain functional properties, namely protein solubility, emulsifying capacity, and viscosity, both in meat and in fish.

Correlations between these three functional properties were examined in an attempt to find the easiest and most sensitive method of analysis.

High correlation among the different functional properties tested was found only in the case of fish. This, together with the significant variations in the viscosity values found during the storage period, suggests that the analysis of apparent viscosity is a valuable indicator method for determining alterations occurring in the functional characteristics of fish protein.

\section{Introduction}

The functional properties of proteins comprise all physico-chemical properties affecting the behaviour of such proteins during food processing.

The following are particularly important functional properties of meat and fish myosystems: protein homogenate solubility, emulsifying capacity and, to a lesser extent, viscosity.

The textural properties will depend largely on protein solubility, especially in the case of fish (Sikorski, 1977), though the emulsifying capacity is important in the case of meat and fish to be processed as sausage. There are many references in the relevant literature discussing the interrelationships between these properties; thus, Grabowska \& Sikorski (1974) indicated that emulsifying capacity in fish depends on protein solubility and is more sensitive than solubility as a source of information on structural changes that take place in the protein molecules.

On the other hand, Carpenter \& Saffle (1965) pointed to a close correlation between viscosity and emulsifying capacity. Froning (1976) likewise reported

Authors' address: Instituto del Frio, Ciudad Universitaria, Madrid 3, Spain.

0022-1163/83/1200-0731 \$02.00 (C) 1983 Blackwell Scientific Publications 
that viscosity in chicken can be considered indicative of the emulsifying properties.

However, it is generally acknowledged that the salt soluble protein fraction (basically the myofibrillar proteins) shows the strongest emulsifying properties. Gaska \& Regenstein (1982) stated that the insoluble protein fraction (connective tissue and unextracted myofibrillar protein) in the presence of salts also plays an important role in the formation of emulsions, because the effect of salt on the hydration state of the protein and on viscosity may be stronger than its effect on solubility. Anyway, there exist discrepancies in this area that are undoubtedly due to the fact that foods are very complex chemical systems.

The purpose of the present study is to investigate the effect of frozen storage and thawing on certain functional properties, namely protein solubility, emulsifying capacity, and viscosity, in both meat and fish. An attempt is also made to establish correlations between these three functional properties, in order to be able to choose the simplest and most sensitive method of analysis for determining any changes that have taken place in the product.

\section{Materials and methods}

The food samples were purchased at a local market in September. The meat used was pork and chicken (breast) and the fish was blue whiting (Micromesistius poutassou, Risso) and horse mackerel (Trachurus trachurus, L.).

These types of muscle tissue were selected in order to investigate the different properties of myosystems exhibiting different behaviour in response to frozen storage.

After being brought back to the laboratory, the samples were minced in a meat mincing machine with plate orifices of $5 \mathrm{~mm}$. Following this, $300 \mathrm{~g}$ lots were vacuum-sealed in plastic bags.

The samples were then frozen in a blast freezer at a temperature of $-30^{\circ} \mathrm{C}$ and an air speed of $5 \mathrm{~m} / \mathrm{sec}$ and kept in cold store at $-20^{\circ} \mathrm{C}$ for 8 months. The samples were twice subjected to temperature variation once after the first month of storage and again after the seventh month; in both cases, the temperature in the thermal centre of the product was raised at night up to about $-5^{\circ} \mathrm{C}$, and on the following day it was lowered back down to $-10^{\circ} \mathrm{C}$. This was done to accelerate the changes in the characteristics of the proteins and thus make the alterations more evident.

The functional properties investigated were protein solubility (PS), emulsifying capacity (EC) and viscosity (V). The soluble protein losses were determined by the method of Ironside \& Love (1958). The protein extract obtained by homogenizing $100 \mathrm{~g}$ of muscle with $400 \mathrm{ml}$ of a $5 \% \mathrm{NaCl}$ solution $\left(\mathrm{pH} 6.5-7.0,4^{\circ} \mathrm{C}\right)$ for $2 \mathrm{~min}$ in an 'Omnimixer' homogenizer were analysed for $\mathrm{EC}$ and $\mathrm{V}$.

The EC determination was performed three times using the method described by Jiménez-Colmenero \& Garcia-Matamoros (1981), and the results 
were expressed in $\mathrm{g}$ of oil/g of muscle (EC) and in $\mathrm{g}$ of oil/100 $\mathrm{mg}$ of soluble protein. The apparent viscosity was determined with a Brookfield rotational viscometer using the No. 2 rotor at a speed of $20 \mathrm{rev} / \mathrm{min}$ for fish and chicken muscle and a $1 \mathrm{rev} / \mathrm{min}$ for pork muscle. Viscosity readings were taken at least five times over a $20 \mathrm{~min}$ period, beginning $3 \mathrm{~min}$ after starting the rotor, in a temperature range of $5-7^{\circ} \mathrm{C}$.

Each type of analysis was performed at five different times over the storage period ( 8 months) and repeated three times on each occasion.

The degree of significance between the mean values was determined by analysis of variance with an $F$-test.

Regression curves were calculated to clarify trends in the results of different functional tests, and the corresponding correlation coefficients were established. The degree of significance of the correlations were taken from the tables given by Lamotte (1981).

\section{Results and discussion}

The results for protein solubility, emulsifying capacity, and viscosity in the samples analysed through the experimental storage period are shown in Table 1. The initial soluble protein levels were higher in fish than in meat, the highest values being found for fish in horse mackerel and for meat in pork. It can be seen that, throughout the storage period, the myofibrillar protein of meat was more stable than that of fish, as the decrease in solubility is less pronounced, so that in the case of chicken it remained constant and showed no significant difference during the eight months of storage.

Of the fish, horse mackerel generally maintained the largest amounts of soluble protein and, therefore, the greatest stability, whereas blue whiting showed the highest degree of denaturation and protein aggregation. The differences in protein stability between lean and semi-fatty fishes, such as blue whiting and horse mackerel respectively, have been ascribed to the protective effect exerted by neutral lipids in response to the insolubilizing action of free fatty acids (FFA) on the proteins. While in lean fishes (blue whiting) there are no neutral lipids capable of counteracting the action of the FFA, the semi-fatty fishes (horse mackerel) do contain these lipids in sufficient concentration and adequately distributed so that they can act (Labuza, 1971).

Pork muscle initially showed EC values lower than, but very similar to, those in horse mackerel, and chicken showed the highest values, both initially and throughout the storage period (Table 1). In all the samples the EC decreased as the frozen storage time increased, and this phenomenon was more marked in blue whiting and horse mackerel and less evident in pork muscle. The change in the EC could, to a great extent, be due to the loss of protein solubility, as suggested by the fact that storage affects both parameters in the same manner. Grabowska \& Sikorski (1974) suggested that the EC decrease is due to denaturation induced by the freezing process.

The emulsifying capacity expressed in $\mathrm{g}$ of oil/100 $\mathrm{mg}$ of soluble protein 
Table 1. Mean results obtained for the different samples over storage

\begin{tabular}{lllllll}
\hline \multirow{2}{*}{ Sample } & \multicolumn{5}{l}{ Days in storage } \\
\cline { 3 - 7 } Horse mackerel & Analysis & 0 & 30 & 60 & 150 & 240 \\
\hline \multirow{2}{*}{ Blue whiting } & PS & $78.9 \mathrm{a}$ & $54.3 \mathrm{~b}$ & $41.9 \mathrm{c}$ & $38.3 \mathrm{~d}$ & $30.2 \mathrm{e}$ \\
& EC & $48.2 \mathrm{a}$ & $36.7 \mathrm{~b}$ & $35.5 \mathrm{bc}$ & $36.9 \mathrm{~b}$ & $33.9 \mathrm{c}$ \\
& $\mathrm{V}$ & $3926 \mathrm{a}$ & $1760 \mathrm{~b}$ & $814 \mathrm{c}$ & $198 \mathrm{~d}$ & $39 \mathrm{e}$ \\
& PS & $73.5 \mathrm{a}$ & $42.9 \mathrm{~b}$ & $40.3 \mathrm{c}$ & $43.5 \mathrm{~b}$ & $25.5 \mathrm{~d}$ \\
& EC & $53.0 \mathrm{a}$ & $34.7 \mathrm{~b}$ & $33.4 \mathrm{~b}$ & $34.9 \mathrm{~b}$ & $30.1 \mathrm{c}$ \\
& V & $4533 \mathrm{a}$ & $1502 \mathrm{~b}$ & $353 \mathrm{c}$ & $153 \mathrm{~d}$ & $15 \mathrm{e}$ \\
& PS & $57.9 \mathrm{a}$ & $57.7 \mathrm{a}$ & $57.8 \mathrm{a}$ & $58.8 \mathrm{a}$ & $55.6 \mathrm{a}$ \\
& EC & $58.1 \mathrm{a}$ & $48.9 \mathrm{bc}$ & $45.7 \mathrm{~b}$ & $49.6 \mathrm{c}$ & $47.8 \mathrm{bc}$ \\
& V & $2979 \mathrm{a}$ & $3398 \mathrm{~b}$ & $3596 \mathrm{~b}$ & $3408 \mathrm{ab}$ & $3363 \mathrm{~b}$ \\
& PS & $60.0 \mathrm{a}$ & $48.4 \mathrm{~b}$ & $54.9 \mathrm{c}$ & $43.4 \mathrm{~d}$ & $40.0 \mathrm{e}$ \\
& EC & $46.0 \mathrm{a}$ & $44.1 \mathrm{a}$ & $41.5 \mathrm{~b}$ & $40.6 \mathrm{~b}$ & $39.4 \mathrm{~b}$ \\
& V & $76666 \mathrm{a}$ & $77083 \mathrm{a}$ & $70300 \mathrm{ab}$ & $65255 \mathrm{~b}$ & $46750 \mathrm{c}$ \\
\hline
\end{tabular}

The means for each type of analysis marked by the same letter are not significantly different $(P>0.05)$.

PS (protein solubility) expresed as percent soluble protein on total protein.

EC (emulsifying capacity) expressed in $\mathrm{g}$ of oil/g of muscle.

$\mathrm{V}$ (viscosity) expressed in cps.

(Table 2) increased with storage time, the opposite of what happened when it is expressed in $\mathrm{g}$ of oil/g of sample, as already seen. The decrease in protein solubility leads to a reduction in the concentration of soluble protein in the medium; this dilution causes an increase in the amount of oil emulsified/unit protein. The interdependence between the protein concentration and the emulsified fat, for which both linear (Carpenter \& Saffle, 1964; Bello, Ripoll \& Larralde, 1978) and curvilinear (Hegarty, Bratzler \& Pearson, 1963; Trautman, 1964) relationships have been found, seemed to resemble, under the test conditions, the latter (curvilinear) relationships in the case of fish and the former (linear) in the case of pork.

This behaviour can be linked to differences in the interface films due to the different soluble protein concentrations in the medium (Graham \& Phillips,

Table 2. Emulsifying capacity in $\mathrm{g}$ of oil/100 $\mathrm{mg}$ of soluble protein

\begin{tabular}{llllll}
\hline \multicolumn{5}{l}{ Days in storage } \\
\cline { 2 - 6 } Sample & 0 & 30 & 60 & 150 & 240 \\
\hline Horse mackerel & 34.75 & 38.48 & 48.27 & 54.79 & 63.85 \\
Blue whiting & 46.95 & 52.64 & 54.04 & 52.29 & 76.86 \\
Chicken & 52.92 & 44.61 & 41.61 & 44.43 & 45.25 \\
Pork & 42.88 & 50.94 & 42.27 & 52.31 & 55.17 \\
\hline
\end{tabular}


1976), which, according to Bello et al. (1978) determine the magnitude of the emulsifying capacity of the system.

In a biological system, with its highly complex medium, there must necessarily be many factors affecting the relationship between EC and PS; however, in the present instance, when the emulsifying capacity is compared at similar protein concentrations, no important differences were found in the emulsified oil in the different samples once the effect of dilution had been obviated, which seems to suggest that the emulsifying properties of the soluble proteins are similar in horse mackerel, blue whiting, pork and chicken.

The highest viscosity values were found in pork, substantially higher than in the rest of the samples. Except in the case of chicken muscle, in which viscosity remained constant, frozen storage resulted in significant decreases in the viscosity of the protein extracts; this decrease was linear for the pork and exponential for the fish. Although viscosity depends on many parameters, trends in this property can generally be related to changes in protein solubility, as will be seen later.

When the significant differences between the values for the different functional properties obtained over the storage period and given in Table 1 are compared, it is found that the changes undergone by the proteins are most clearly reflected by the trends in protein solubility and viscosity.

Table 3 presents the correlation coefficients between the functional properties investigated. There was a highly significant correlation between PS and EC in fish, but this was not the case for chicken and pork. Grabowska \& Sikorski (1974) observed a similar phenomenon in cod minces reporting that emulsifying capacity and protein solubility, which are significantly correlated $(r=0.85-0.95)$, decreased due to denaturation and protein aggregation induced by frozen storage.

In the present experiment no significant correlations were found for these two parameters in chicken and pork, corresponding with the results reported by Ockerman \& Crespo (1981) for homogenates of beef.

Table 3. Correlation coefficients between the functional properties evaluated

\begin{tabular}{llll}
\hline Analysis & Sample & $\begin{array}{l}\text { Emulsif. } \\
\text { capacity }\end{array}$ & Viscosity \\
\hline Soluble protein & Horse mackerel & $0.882^{*}$ & $0.988^{*}$ \\
& Blue whiting & $0.912^{*}$ & $0.925^{*}$ \\
& Chicken & 0.036 & 0.129 \\
& Pork & 0.728 & $0.763^{*}$ \\
Emulsifying & Horse mackerel & & $0.923^{*}$ \\
capacity & Blue whiting & & $0.954^{*}$ \\
& Chicken & & 0.668 \\
& Pork & & 0.145 \\
\hline
\end{tabular}

* Significant at $99 \%$. 
Highly significant correlations between protein solubility and viscosity were detected in the case of fish and pork but not in the case of chicken (Table 3). Although viscosity is determined by a number of factors, such as $\mathrm{pH}$, ionic strength, and temperature, the primary factor affecting it is the protein concentration. Thus, in the relevant literature there are data recording the existence of various direct relationships between these two parameters (Kinsella, 1976; Hutton \& Campbell, 1977), as well as the dependence of viscosity on molecular interactions and protein aggregation (Nakayama et al., 1979). Nevertheless, on occasion it has not been possible to establish significant correlations (Ockerman \& Crespo, 1981).

Emulsifying capacity and viscosity were significantly correlated in horse mackerel and blue whiting (Table 3 ). Since changes undergone by these functional properties are to a great extent determined by the same factors, it seems logical that there should be such close correlations between them. Although Carpenter \& Saffle (1965) found a strong correlation between these parameters $(r=0.97)$, in the present experiment no such high correlation was found in pork or chicken.

It can generally be said that, while significant correlations can be established between protein solubility, emulsifying capacity, and viscosity in fish, the same does not hold true in the case of meat. Among the different factors conditioning emulsifying capacity and viscosity, the main one is soluble protein concentration, which decreases throughout the frozen storage period as a result of protein denaturation and aggregation. Since soluble protein concentration shows greater variation in fish than in meat due to differences in the stability of the proteins in these products, the decrease in protein solubility might be the determinant of the variations detected in emulsifying capacity and viscosity. The same cannot be said, however, for meat, in which, due to lower levels of protein denaturation and aggregation, the combined action of other factors masks the effect of variations in concentration of soluble proteins.

In the case of fish the strong correlations found between the different functional properties tested (Table 3), as well as the variations in viscosity values during the storage period, which cause the values of apparent viscosity obtained in each control to be significantly different from all the others (Table 1), seem to suggest that, among the functional properties tested, apparent viscosity most clearly reflects the changes undergone by the proteins.

In view of the foregoing discussion, it would appear that further research should be undertaken on this point to apply the apparent viscosity test to other fish species of differing characteristics, in order to confirm its usefulness as a routine analysis for quality control in the case of frozen fish.

\section{References}

Bello, J., Ripoll, J. \& Larralde, J. (1978) Anal. Bromatol. XXX-2, 163.

Carpenter, J.A. \& Saffle, R.L. (1964) J. Fd Sci. 29, 774.

Carpenter, J.A. \& Saffle, R.L. (1965) Fd Technol., Chicago, 19, 111. 
Froning, G.W. (1976) Fd Technol,, Chicago, 30, 50.

Gaska, M.T. \& Regenstein, J.E. (1982) J. Fd Sci. 47, 1438.

Grabowska, J. \& Sikorski, Z. (1974) Proc. IV Int. Congr. Fd Sci. Technol., Topic 2, Madrid.

Graham, D.E. \& Phillips, M.C. (1976) Theory and Practice of Emulsion Technology. (Ed. A. L. Smith) p. 75. Academic Press.

Hegarty, C.R., Bratzler, L.J. \& Pearson, A.M. (1963) Fd Technol., Chicago, 21, 1024.

Hutton, C.W. \& Campbell, A.M. (1977) J. Fd Sci. 42, 457.

Ironside, J.I.M. \& Love, R.M. (1958) J. Sci. Fd Agric. 9, 597.

Jiménez-Colmenero, F, \& García-Matamoros, E. (1981) Proceedings of European Meat Research Congress. 351. Vienna, Austria.

Kinsella, J.E. (1976) CRC Crit. Rev. Food Sci. Nutr. 7, 219.

Labuza, T.P. (1971) CRC Crit. Rev. Food Technol. 2, 355.

Lamotte, M. (1981) Estadistica Biológica. (Ed.S. A.Toray-Masson), p.159. Barcelona, Spain.

Nakayama, T., Niwa, E., Hamada, I. \& Shin, C. (1979) J. Fd Sci. 44, 1106.

Ockerman, H.W. \& Leon Crespo, F. (1981) Proceedings of European Meat Research Congress, 266. Vienna, Austria.

Sikorski, Z.E. (1977) Bull. I.I.R., Annexe 1977-1. Karlsruhe.

Trautman, J.C. (1964) Fd Technol., Chicago, 18, 1065.

(Received 2 March 1983) 